\title{
Self-Reflections of Introvert Students towards Problems of Speaking English
}

\author{
${ }^{1 s t}$ Reni Handayani \\ Graduate School \\ Universitas Negeri Yogyakarta \\ Yogyakarta, Indonesia \\ renihandayani1516@gmail.com
}

\author{
${ }^{2 n d}$ Widyastuti Purbani \\ Graduate School \\ Universitas Negeri Yogyakarta \\ Yogyakarta, Indonesia \\ purbani@uny.ac.id
}

\begin{abstract}
This article reports the findings of a phenomenological study investigating introvert students' lived experiences in learning to speak English as long as they were studying in Senior High School. Being reflective is one of the characteristics of the students who are inclined to have introvert personality. This study was carried out to answer the research questions about personality problems as the intrinsic side of affectivity that they ever faced in speaking English after they made self-reflections. Participants of the study were five students grade XII of academic year 2017/2018 in a public Senior High School who had just completed the National Examination. Students' reflective writing and semi-structured interview were used to collect the data of this study. The data were organized, summarized and interpreted to get the essence of the participants' experiences. The findings showed that there was one main affective problem experienced by the participants that was language anxiety in speaking English consisting of communication apprehension and fear of negative social evaluation (Horwitz, Horwitz, and Cope, 1986; and MacIntyre and Gardner, 1989, 1991, in Brown, 2007, p. 162). This research also found the participants' self-reflections towards the language anxiety including determining directions and thinking of consequences (Bandura in Hergehahn and Olson, 2008, p. 385). The participants did self-reflections to cope with language anxiety that had hindered them to achieve success in speaking English.
\end{abstract}

Keywords-speaking skill, introvert personality, self-reflection, language anxiety

\section{INTRODUCTION}

In the process of English language teaching in Indonesia, teachers need to know what problems experienced by introvert students in learning speaking skill. Introverts are those who are known quiet and passive, but they are experts in selfreflection. Certainly, they must have experienced problems when speaking. That is why it is important to investigate the problems that hinder those introvert students from being able to speak English.

Speaking is the main target to be examined in this study which is one of the productive skills of English. Amiri, Othman, and Jahedi (2017) state that the key to successful communication is to be able to speak effectively and accurately as it occupies as essential positions in individual and social life. It can be said that learning speaking has become the precedence because this skill is very crucial when using English to communicate. Concerning with the importance of English speaking skills, there is a requirement for English teachers in Senior High School to meet the needs of students by adjusting to local learning conditions and situations. The teachers and students need to have positive relationships so that teaching and learning to speak English will succeed (Hattie \& Yates, 2014, pp. 16-17).

Speaking is a very crucial skill in communication, and it is one of the difficult skills in English language. The skill of speaking needs to be trained through learning or practice. According to Pollard (2008, p. 33), speaking is one of the most difficult aspects to be mastered by students. Speaking is not the speech of what is written as McDonough, Shaw and Masuhara (2013, p. 156) state that speaking is not the oral production of written language, but there is the mastery of wide range of subskills to achieve overall spoken language competence in which people commonly judge language competence from speaking rather than the other three skills. Speaking is the most fundamental skill for success in foreign language learning as well as listening. Palmer (2014, p. 9) says that speaking and listening are embedded so deeply in many aspects of life where most of people do not think much about them where they are the foundation of human interaction.

In learning to speak English, the students may have diversity in personality where it surely affects their efforts to achieve success. In short, the students' personality is one of factors determining their achievements in speaking English. It should be noted that the students have two basic psychological types of personality: introversion and extroversion as its counterpart (Jung, 1921 in Bishop, 2014, p. 135). It is asserted by Cain $(2012$, p. 6$)$ that persons who are thought as quiet are introverts. She says that quiet is the power of introverts in a world that can't stop talking. There was no meaningful matter for those who are extrovert in learning to speak English because they are open and talkative, but it is different from introverts who prefer to listen to others' talk and think about information privately (Pritchard, 2014, p. 52). Thus, it can be concluded that the introverts certainly face problems in speaking English.

Introvert students have some characteristics that they prefer to stay for long in solitude rather than public places. 
They also like to study, work and spend time alone rather than in group of people. Mostly in the classrooms, introverted students are identified as passive students. Ancowitz (2010, p. 1) illustrates an introvert is seen silent at meetings; eating lunch alone; and promoted by others who are less talented. She continues that introverts are known that they have something to say but something stops them, perhaps, they do not want to draw much attention to themselves. It is stated more by Ancowitz (2010, p. 2) that introverts prefer to think before they speak and they tend to be reflective. The word "reflective" here is the point that has made the researchers interested to examine this characteristic as it is their strength in learning. Therefore, this study is focusing on selfreflections of the introvert students towards problems of speaking English.

Self-reflection is done when the introvert students think carefully about their past experiences in order to detect the speaking problems they had and how to cope with the problems. Zimmerman (1998, p. 2) states that self-reflection consists of processes that occur after learning efforts and influences students' reactions to the experiences. Bandura in Hergehahn and Olson (2008, p. 385) mentions that selfreflection is the ability of metacognition to reflect on actions that have been done so as to determine direction, think consequences, and make plans for the future. Schunk (2012, p. 127) also clarifies what Zimmerman states that there are behaviorally and mentally responses to their own efforts especially in learning English speaking skill.

Anxiety was found as the affective problem that the introvert students faced in speaking English. It is important to understand the meaning of this term. Because of the characteristics of those introverts who prefer to think first before speaking, they can think of various things on their minds which then make them anxious and hinder them to practice speaking (Ancowitz, 2010, p. 1; Pritchard, 2010, p. 52). According to Brown (2007: 161), anxiety plays an important affective role in language learning called language anxiety. In Brown (2007: 162), foreign language anxiety is identified by Horwitz, Horwitz, and Cope (1986), and MacIntyre and Gardner $(1989,1991)$ in three components: first is communication apprehension that arises from the inability of students to express maturity thinking and ideas; second is the fear of negative social evaluation that arises from the student's need to make positive social impression from others; and third is text anxiety or fear of academic evaluation. If the introvert students experience these problems, their speaking performance will be problematic even though they actually have capabilities to have a good achievement in speaking in accordance with the demands of teachers and curriculum.

Several studies have been conducted to examine the problems of speaking English as a foreign language, namely anxiety where it was the results of other problems. Curtone (2009) discussed the reasons for language anxiety that affected students' performance in oral tasks, which was due to the existence of apprehension, social evaluation, and inter-learner competition. He added that further study of anxiety related to motivation, personality, and self-confidence was recommended. Zhiping and Paramsivam (2013) then found that anxiety was the result of fear of negative evaluation and communication apprehension by the reasons they the students were afraid of public speaking, shy and inaccurate when speaking. Their study revealed that the students coped with language anxiety by using strategies of keeping silent and preventing eye contacts with others. Moreover, Indrianty (2016) also investigated about anxiety in speaking English, and she found that the sources of anxiety were communication apprehension, test anxiety, and fear of negative evaluation. She also mentioned another findings that there were two types of anxiety which were trait anxiety and state/situational anxiety. Those three studies were carried out with their purposes to help the teachers understand the students' problem and how they reflected themselves to deal with the problems. It was expected that the teachers might find appropriate techniques or strategies to facilitate the students in achieving success in speaking English, especially for those who were inclined as introvert students.

It is already known that many studies have been conducted to examine the students' problems of speaking English and finding out how they deal with the problems, but the studies are more focused on passive students in general. Not many studies have investigated the speaking problems especially the language anxiety of the students who have an introverted personality where they have self-reflection ability more than extroverts. Therefore, the researchers have decided to examine this phenomenon on how introvert students were still not yet successful in speaking. This article presents a phenomenological study on the lived experiences of introvert students in learning to speak English. This study is aimed to answer the research questions about what problems experienced by introvert students in speaking English and how they reflect themselves towards the problems.

\section{METHODS}

The researchers selected phenomenology as a qualitative method to do this research. The researchers used this approach to do in-depth inquiry towards participants to share their experiences in learning to speak English focusing on the problems they ever faced. This phenomenological research was to find out the essence of the lived experiences of the participants related to the phenomenon that learning English speaking skill was problematic for introvert students. This study was conducted in a Senior High School in Central Java where the participants were five introvert students who had just completed the National Examination as a requirement to graduate. Pseudonym was used to protect the identities of the participants. The researchers executed this research on June 2018 in the natural settings of the participants.

The role of the researchers were as the main instruments where students' reflective writings and unstructured interviews were as the other instruments that were also used to collect data for this research. The researchers used students' reflective writing as a data collection technique by referring to the characteristic of the participants as introvert students in which they were reflective. Moreover, the researchers 
conducted semi structured interviews to each of the participants concerning with what they had written in their reflective writing worksheets. The interviews were then transcribed verbatim.

After data collection, the researchers then analyzed them in three steps: data organization, data summary, and data interpretation. These were done to achieve final concepts as the answers of the research question. To make the data credible, the researchers used some strategies such as having prolonged engagement with the participants, bracketing the researchers' own thoughts, triangulation, and the researchers' reflections.

\section{FINDINGS AND DISCUSSIONS}

Participants' voices from students' reflective writings and semi-structured interviews were combined based on the research questions. They were centered on the issues speaking problems of the participants as they were identified as introverts and how they reflected themselves towards the problems. In relations to their inclinations as introvert students, all five participants have shared their lived experiences as long as studying English in the Senior High School. They faced speaking problems in some way, and they actually make efforts to cope with the problems. Their introverted characteristic as reflective students have influenced their efforts to determine solutions in dealing with the problems they experienced in speaking English. In this study, language anxiety was found as the main problem as the results of other problems that were communication apprehension and fear of negative evaluation from others. Moreover, the participants' self-reflections were elaborated then to understand how they coped with language anxiety. The findings of this phenomenological study will be elaborated and discussed below.

\section{A. Language Anxiety}

Anxiety was the main problem of the participants as they were inclined to have introverted personality. When the participants felt anxious was that they worried about speaking English, this feeling was experienced by them before practicing speaking in the classroom. The feeling of anxiety lied on the minds of the participants as explained by Ancowitz (2010, p.1) and Pritchard (2014, p. 52) that the characteristics of introverts prefer to think before speaking and sometimes it makes them think a lot of things then they get confused and anxious about what to say. Some of the participants admitted that they suffered anxiety in speaking English. The following conversation was a part of the interview with Participant 2.

R: How about anxiety?

$\mathrm{P} 2$ : Yes, if feeling anxious was yes.

Moreover, Participant 4 also wrote the statement bellow as she said that anxiety was her problem too. She shared her experiences of learning English speaking skill that there was anxiety she suffered, then she explained the anxiety by the words fear of inability and fear of being wrong.

There was anxiety, fear if I might not be able then, if wrong how. That's it anyway.
The language anxiety they experienced had been found that it is related to affective roles in speaking (Brown, 2007, p. 161). The researchers identified that the participants' anxiety was caused by other affective problems namely communication apprehension and fear of negative social evaluation which are the components of language anxiety pioneered by Horwitz, Horwitz, and Cope (1986), and MacIntyre and Gardner $(1989,1991)$ in Brown (2007, p. 162). In fact, they sparked the three components in which the other was test anxiety or apprehension over academic evaluation. However, the researchers only focus on examining the two components mentioned earlier: communication apprehension and fear of negative social evaluation.

\section{1) Communication apprehension}

The researchers discovered that almost all participants experienced apprehension in oral communication of using English language. As explained by Horwitz, Horwitz, and Cope (1986), and MacIntyre and Gardner (1989, 1991) in Brown (2007, p. 162) that communication apprehension is arisen from the students' inability to express their thoughts and ideas carefully, as well it was found by the researchers. Previous researchers such as Curtone (2009), Zhiping and Paramisivam (2013), and Indrianty (2016) revealed the same findings that the students' anxiety was caused by communication apprehension problems. To enhance that, in detail, the researchers also obtained information about the types of apprehension experienced by the participants where they tended to have an introverted personality including fear of being wrong, stage fright, fear of being misunderstood, fear of being unable, and fear of forgetting.

\section{a) Fear of being wrong}

Fear of being not correct when speaking English was most widely experienced by the participants and it was the beginning of the speaking problems. Fear of being wrong was as the foundation that it created blocks that the participants experienced difficulties to achieve success in speaking English. For example, Participant 1 wrote in her reflective writing worksheet that she experienced fear of being wrong.

... did not understand the materials delivered by the teacher, I wanted to ask but I was afraid of being wrong in English pronunciation.

She told that she feared of being wrong in pronouncing English words so that she canceled her desire to ask questions related to the materials she did not understand.

Participant 3 asserted that he was also afraid of being wrong in speaking English. He wrote in his reflective writing as follows.

In the case when I had to speak English, I felt afraid of being wrong whether what I pronounce might be wrong and the interlocutors I talked to might not understand.

His fear was about being wrong in English pronunciation. He was afraid if he was wrong then his interlocutors might not understand his speech. This fear had resulted anxiety.

In addition, Participant 4 also shared with the researchers in the interview concerning with her fear of being wrong.

If we spoke English, moreover in the classroom, if we wanted to initiate a talk, we were just afraid, uh the grammar was wrong, uh the vocabulary was not correct though for the verb had to be verb II or verb III. So, if we 
wanted to learn to speak English, we were inhibited then. We feared of being blamed.

She used the pronoun "we" as the first person plural rather than "I". It indicated that she seemed not confident enough to say that it was surely her own problem. Her problem was that when she had a willing to initiate a talk, she feared if her grammar and vocabulary were wrong when she started to speak. Her fear also caused anxiety too.

Furthermore, fear of being wrong was also the problem experienced by Participant 5. The following was a piece of the conversation of Participant 5 with the researchers in the interview.

\author{
R: If forgetting, why? \\ P5: Afraid of being wrong. \\ $\mathrm{R}$ : Indeed if later wrong, why? \\ P5: That was the weakness. \\ $\mathrm{R}$ : Were you afraid of being laughed by friends? I believe your friends \\ did not like to laugh at you. \\ P5: No. \\ R: But, don't you like making mistakes? \\ P5: Yes. \\ R: Do you want everything to be perfect? \\ P5: Yes.
}

The researchers previously asked about forgetting when speaking English then Participant 5 said that he was afraid of being wrong as it was seen as the consequence of forgetting. Although forgetting was not something conscious, he stated that it had influenced his fear of being wrong and he noticed that it was his weakness. He said that he did not like making mistakes and he said yes that he wanted everything to be perfect. That was all the participants' apprehension of being wrong.

\section{b) Stage fright}

Stage fright was happened because the participants had the feeling of fear when they were about to perform or practice speaking English in public. It was written by Participant 1 as her self-reflection that she experienced stage fright when speaking English in front of public. Stage fright was always related to public speaking.

... difficult to speak English in public ...

In this case, the public was in front of her teacher and friends in the classroom.

Participant 4 also mentioned the same problem in the interview. She said the following statements.

Many have not been resolved. Many! I wonder how? Boldness to speak English in public alone was very difficult, especially if the people who heard it said: "Uh, what's she talking, what's she talking about?" So how do I feel then? I do not need to learn English, what for? Maybe that's all.

Participant 4 shared with the researchers that she still had many problems that had not been overcome. It can be inferred that it was difficult for her to arise her boldness for public speaking. She had a fear to speak English in public, and she might feel stage fright. Then it caused the problems such as feeling anxious of being misunderstood and feeling unmotivated.

Moreover, Participant 5 wrote the following statement in his reflective writing worksheet. He said that:
... (public speaking and stage fright are still inseparable).

It was convinced again that stage fright as the second type of fear in speaking English could not be separated from public speaking. Participant 5 realized these inseparable things had hindered him to speak English successfully.

\section{c) Fear of being misunderstood}

Being misunderstood was that the participants assumed that their listeners have understood them but they had not. Participant 3 wrote the following statements that he had a feeling of fear in speaking English.

In the case when I had to speak English, I felt afraid of being wrong and the interlocutor I talked to might not understand.

He was anxious if his speech might be misunderstood by his listener after his fear of being wrong. It was his problem that hindered him to practice speaking English.

Moreover, it was said by Participant 4 that she was also anxious if what she was going to say might not be understood. She shared with the researcher in the interview that:

Many have not been resolved. Many! I wonder how? Boldness to speak English in public alone was very difficult, especially if the people who heard it said: "Uh, what's she talking, what's she talking about?" So how do I feel then? I do not need to learn English, what for? Maybe that's all.

Previously, she mentioned that many of her problems were not yet resolved. Getting boldness to speak in public was difficult for her because she was anxious if her speech might not be understandable. She had anxiety if her listeners did not understand her when delivering message through speaking English. She somewhat felt that there was no need to learn English if she was misunderstood.

\section{d) Fear of being unable}

This type of apprehension was shared by Participant 4 that she worried if she might not be able to speak English. The following was a quote from the conversation in the interview when the researcher asked her about anxiety problem.

There was anxiety, fear if I might not be able then, if wrong how. That's it anyway.

For her, if being unable, there might be being wrong. She experienced this anxiety as it made speaking English was problematic for her. Being anxious if she might not be able to speak had made her failed to have good achievement in English speaking skill.

\section{e) Fear of forgetting}

Forgetting was the last type of communication apprehension in speaking English. For example, it happened to Participant 5 as it can be seen in the piece of a conversation of the interview bellow.

$\mathrm{R}$ : After that, you were called by the teacher or anyone was allowed to practice in front of the class, did you ever feel anxious?

P5: Yes.

R: How was your anxiety?

P5: If forgetting, you know that.

In the beginning, the researchers asked him whether he ever experienced anxiety in speaking practices, and he said yes. He felt anxious if he might forget about what to say in front of the 
class when speaking. Thus, he considered this as his problem of speaking English.

\section{2) Fear of negative social evaluation}

There were fears of negative evaluation from others that the participants suffered which made them feel anxious to speak English. It might be because the participants had bad experiences when speaking in front of the class where their friends did not give good impressions. As previously elaborated where Horwitz, Horwitz, and Cope (1986), and Macntyre and Gardner $(1989,1991)$ in Brown $(2007$, p. 162) asserted that fear of negative social evaluation is where the students need to get positive feedbacks from others, as well as participants of this study. But because of their negative experiences, they became afraid of the practice of speaking English again, and this also prevented them from achieving success in this skill.

As a problem that caused participants suffering anxiety, fear of negative social evaluation has been investigated by many researchers. The researchers tried to convey in detail what participants had shared about their fear of negative evaluation from their friends when speaking English. Like Curtone (2009), Zhiping and Paramsivam (2013), and Indrianty (2016) about this type of fear, as well as the researchers who found the same thing when conducting this research. The types of fear include fear of being laughed at, fear of being blamed, and fear of bullying.

\section{a) Fear of being laughed at}

Being laughed at was that the participants might think that they were stupid. They feared to be laughed at by their friends if they made mistakes when speaking English. That was why they preferred to keep silent. For instance, Participant 1 said that:

Being asked by the teacher or friends was difficult to answer, then occasionally feeling reticent, then I feared of being wrong because if I was wrong I might be bullied later on, then being laughed by friends, well I was so shy then ... I prepared first. If spontaneously speaking, I was afraid of being wrong. If wrong, I might be laughed then it might trouble me.

She stated that when the teacher asked question to her, and her friends also asked question as well, she got difficulty to answer. It seemed that she had a negative experience of being wrong when speaking English so that she became afraid of being wrong again because when she was wrong her friends laughed at her. Consequently, she became anxious if she might be laughed at by her friends when she made mistakes in speaking. She explained at the time of the interview that before she spoke English spontaneously, she had actually prepared about what to say. However, she still felt afraid if she might be wrong then. As a result, she got anxiety if her friends might laugh at her because of her mistakes, and she might get trouble in her speaking practices.

In addition, Participant 4 asserted the same thing as well that she experienced anxiety if she might be laughed at by her friends when she was wrong in speaking English. She stated that:

So, if I answered it wrong, I might be laughed at.
In this case, Participant 4 was asked by the teacher or it might be by her friends, but then she answered the question not correct. Finally, she felt anxious that she might be laughed at by others. It indicated that she seemed that she ever had bad experience in the past. She might ever made mistakes when speaking English and her friends laughed at her. She then had this belief that when she was wrong, she might be laughed at by others.

\section{b) Fear of being blamed}

Blame was when other students said or thought that the participants did something wrong. For example, Participant 4 wrote as in the following.

And also when speaking, sometimes I was afraid to be blamed like "Uh ... the grammar was wrong, the sentence sequence was less precise". So, when we wanted to speak, we were afraid first if anyone might say so ... If we spoke English, moreover in the classroom, if we wanted to initiate a talk, we were just afraid, uh the grammar was wrong, uh the vocabulary was not correct though for the verb had to be verb II or verb III. So, if we wanted to learn to speak English, we were inhibited then. We feared of being blamed.

She might have experienced of being blamed by her friends so that she could say that she was afraid then to be blamed if she made mistakes in speaking English. She said the mistakes might be in grammar and the accuracy of the sentence sequence. Her fear of being blamed had hindered her to speak. Her fear of being wrong when speaking English was actually as a cause of fear of being blamed. She said as well that it might cause inhibition in speaking. Being blamed by friends had made her discouraged to speak.

\section{c) Fear of bullying}

Bullying was commonly experienced by introvert students that others hurt or frightened them when they made mistakes in English speaking classes. For instance, it was shared by Participant 1 in the interview that she experienced bullying after making mistakes in speaking. She said that:

Being asked by the teacher or friends was difficult to answer, then occasionally feeling reticent, then I feared of being wrong because if I was wrong I might be bullied later on, then being laughed by friends, well I was so shy then ... The problem was how if the people like me were noticed and not being bullied by friends, how to be able to be ourselves.

Indeed, the problems were sequential where one problem caused other problems. Because of fear of being wrong, Participant 1 then experienced other fear if she might be bullied by her friends in the classroom besides other problems like anxiety if being laughed at and shyness. In addition, being noticed she meant was that she expected if her teacher noticed her within their introverted personality, and she also hoped if her friends might not bully her. She seemed clearly that she was anxious of bullying. It might be because she ever had experienced being bullied by her friends when speaking English.

\section{B. Self-Reflections towards Language Anxiety}

All five participants experienced language anxiety caused by their apprehension when communicating with English and they also experienced fear of negative evaluation from their friends in the classroom. When they told their experiences about these speaking problems, the researchers could feel that their styles of speaking showed clearly their characteristics as 
introverted students. Ancowitz (2010, p. 1) states that introverted students tend to think before speaking, and rightly, the researchers also find the participants do the same thing. As self-reflection is their power of introverts (Ancowitz, 2010, p. 2 ), in this study the researchers also identified that the participants always seemed to reflect themselves about their experiences of learning to speak English in Senor High School.

Self-reflections were carried out by the participants when they thought carefully about their experiences to detect the language anxiety they experienced and how they dealt with the problem. They did self-reflections on their minds first and then expressed them through verbal and written words to the researchers. As expressed by Zimmerman (1998, p. 2) that the process of self-reflection occurs after learning efforts that affect the reaction or response of students towards their experiences, so is this study. The researchers tried to elaborate on how their reactions were in the past about language anxiety, how they faced the problem.

The researchers found that the participants had metacognition abilities as it was stated by Bandura in Hergehahn and Olson (2008, p. 385) where they reflected their actions or experiences to determine directions, think consequences, and make plans for the future. The researchers also found that the participants responded to their own efforts in learning speaking English behaviorally and mentally when they suffered from language anxiety (Schunk, 2012, p. 127). Self-reflections from the participants obtained from reflective writing and interview were the efforts they made to overcome their anxiety problems. The participants had determined directions to cope with communication apprehension and thought of the consequences to overcome fear of negative evaluation from their friends.

\section{1) Determining directions}

All participants, as they were identified as introvert students, actually knew their inability to speak English which caused them suffering communication apprehension. They felt that they did not have enough vocabulary when speaking. They also said that their pronunciation ability was still lacking. Likewise with grammar knowledge, they stated that they needed to improve it. From the information obtained, the researchers found that when they reflected themselves, they had actually determined directions to overcome the communication apprehension problems (Bandura in Hergehahn and Olson, 2008, p. 385). The following are some of the directions they had determined to overcome language anxiety which was as the result of their apprehension in oral communication.

\section{a) Enlarging vocabularies}

Almost all participants realized that their vocabulary mastery in English was still lack so that they suffered communication apprehension when speaking English. This was the first direction determined by them to cope with language anxiety. It was already known that vocabulary is one of the components of speaking. In the interview with Participant 4, the researchers found that she tried to enlarge her English vocabulary because she was aware that her vocabulary mastery was lacking. She stated that:
... but if personally learn maybe from movies, English movies. So I listened while I was looking at the subtitle. So maybe, oh that person was talking this way, maybe I know what was meant. And I think that the vocabulary became acquired by this listening technique ... if the vocabulary itself, that was if the vocabulary might be from dictionaries.

To improve her vocabulary, she was using a dictionary. She enlarged her vocabulary through watching English movies by seeing subtitles that were likely to be in Indonesian, and then the vocabulary would increase. She used listening technique. Through the self-reflection that she did by determining the direction, she seemed convinced that she could overcome language anxiety caused by communication apprehension.

\section{b) Learning more about pronunciation}

Some of the participants shared this second type of direction that they determined as they reflected the language anxiety problem which was caused by their communication apprehension. Learning more about pronunciation was really helpful for them to be more capable in speaking English. Participant 1 shared the following statements in the interview.

It was on Google Translate that there was a way of pronunciation voice on the speaker's symbol. I turned it on to listen. Then, on my mobile phone, I often listen to English songs I liked, so it could flow. And from the movies in English that it was very helpful.

She used Google Translate program in the Internet to help her in practicing English pronunciation. She often turned on the speaker symbol to listen the sound of the English words pronunciation that she had translated from Indonesian. She also frequently listened to English songs in her mobile phone. She then often watched English movies that she felt that they were helpful for her to practice English pronunciation. When she was capable to pronounce the words, she also believed that she might not experience communication apprehension again when speaking. Even there was still apprehension in speaking English it might be less than in the previous because the inability to pronounce had become less.

\section{c) Learning more about grammar}

Grammar is the last component that everyone should master if he or she wants to be able in speaking English. Some participants had reflected themselves towards language anxiety, in this case was communication apprehension as the cause, where they determined directions to solve the problem and one of them was learning and practicing grammar frequently. Participant 2 had told the researchers in the interview. Here was a piece of the conversation with him.

R: Well about this, the problem of arranging words you said before, if you were speaking English or you were presenting or practicing English alone in front of the class, well if you experienced difficulties to put the words together, what did you do?

P2: Commonly, I asked my friends who were better in English. If my friends were not able to answer, then I asked the teacher.

R: To the teacher? Well, what happened then after you asked?

P2: Well, after I asked, later on I might know the problem, what was wrong, so I might know then.

He told the researchers that he had problem in arranging the English words when speaking English. He got difficulties to put the words together into sentences. It indicated that his ability in English grammar was still low. He realized about it so that he suffered communication apprehension that resulted his language anxiety. He then reflected his experience by 
determining what he had to do to solve the problem. Generally, he asked his friends or his teacher if he had problem in spoken grammar. Then, he learned the correct ones so that his apprehension might be overcome.

\section{2) Thinking of consequences}

To overcome the problem of the participants' fears of negative evaluations from their friends, they also reflected on the consequences (Bandura in Hergehahn and Olson, 2008, p. 385) of their efforts in speaking English. So, before acting, they firstly thought about what would happen then after they made speech. They did this intentionally to overcome anxiety caused by their fear of responses or negative feedback from their friends. The participants were afraid that they might get impressions that were negative from others. Some of the ways they did to overcome anxiety such as sitting in front seat, thinking carefully before speaking, and keeping silent. They did these things by thinking about all the consequences that would occur when speaking English where their abilities were still lacking.

\section{a) Sitting in front seat}

Within her fear of negative evaluation from others, Participant 1 had already reflected herself by thinking of the consequences if she would decide to make speech. She knew that she got apprehension in speaking because her inability which might be in vocabulary, pronunciation or grammar that caused her having suffering anxiety. After determining her directions to cope with anxiety, she then thought about any consequences that might happen. Sitting in front bench was what she reflected to avoid her fear of negative social evaluation. ... I was sitting in front seat, close to the teacher. So, if I wanted to ask
questions, I could directly ask in front of the teacher. Even if reading and
I did not know how to pronounce the words, the teacher might notice me
and correct my wrong pronunciation.

Because she was afraid of getting negative impressions from her friends, she tried to avoid that by sitting on the front seat. So, if she wanted to ask the teacher questions in English, she could immediately ask in front of the teacher in a voice that was not too loud. She thought about this because she did not want others to know if she made a mistake in speaking the English word. She did not desire if her friends might identify her weaknesses of speaking English. So, she tried to avoid these consequences that could occur.

\section{b) Thinking carefully before speaking}

The act of thinking carefully before speaking was caused by the participants' thinking about the consequences that would occur if they spoke English. This is one of their personality characteristics as introverts. Participant 5 wrote simply in his reflective writing as follows.

... thinking carefully of what to say.

He looked like a thinker. Before he spoke or acted, he always thought first of what would happen later. He did have experience of getting negative impressions from his friends which made him afraid to speak English. So, to overcome his fear of negative social evaluation which would lead to language anxiety, he was carefully to think about what he would say. He might arrange very tidy every word he wanted to say in front of his teacher and friends.

\section{c) Keeping silent}

Preferring to be silent was the best choice for Participant 1. This was because she was afraid of getting negative comments from her friends when she made mistakes or maybe what she said was offensive to others. In the interview, Participant 1 said her reflection to cope with her fear of negative social evaluation by thinking of the consequences.

Yes, often. The point was that I was afraid of being wrong, afraid of being laughed at, uh, silence, instead of talking but wrong and even hurting the feelings of others, it was better to be silent, right? Say something good or just keep silent!

She had a motto: say something good or just keep silent! She really thought that there would be consequences that happened when she made mistakes. So, to avoid these consequences, she decided just to be silent and thus her fear of negative evaluation could be overcome.

\section{CONCLUSIONS AND RECOMMENDATIONS}

From this phenomenological study, the researchers concluded that language anxiety was the main affective problem in speaking English which was experienced by five participants categorized as introvert students. Their language anxiety was caused by two other problems, namely communication apprehension and fear of negative social evaluation. Their apprehension in oral communication include fear of being wrong, stage fright, fear of being misunderstood, fear of being unable, and fear of forgetting. The participants' fear of negative evaluation from their friends was such as fear of being laughed at, fear of being blamed, and fear of bullying.

The problems they experienced have prevented them from achieving success in speaking English as a foreign language. The strength of the participants as introvert students was selfreflections. They reflected themselves towards language anxiety they suffered by determining directions and thinking of consequences. The directions they determined were by enlarging vocabularies, learning more about pronunciation and grammar. Their ways on thinking of the consequences were like sitting in front seat, thinking carefully before speaking, and keeping silent. They had made these efforts solely to overcome language anxiety where they experienced communication apprehension and fear of negative social evaluation.

However, even though they have detected anxiety in speaking English, and they had made self-reflections to overcome it, their speaking ability still needs improvement. Therefore, it is recommended for further research to investigate how to help introvert students to improve their English speaking skill. It is needed to find appropriate strategies or techniques that the students can apply when they learn to speak English so that they can achieve success no matter they are known as introverts. Subsequent researchers are expected to maximize the strength of introvert students, which is self-reflection, in order to cope with language anxiety they might suffer in speaking English. 


\section{References}

Amiri, F., Othman, M., \& Jahedi, M. (2017). A case study of the development of an ESL learner's speaking skills through instructional debate. International Journal of Humanities and Social Science, 7(2), 120-126. Retrieved from https://www.ijhssnet.com/journals/Vol_7_No_2_February_2017/ 15.pdf.

Ancowitz, N. (2010). Self-promotion for introverts: The quiet guide to getting ahead. New York, NY: McGraw-Hill Companies, Inc.

Bishop, P. (2014). Carl Jung: Critical lives. London: Reaktion Books Ltd.

Brown, H. D. (2007). Principles of language learning and teaching $\left(5^{\text {th }}\right.$ ed.). New York, NY: Pearson Education Limited.

Cain, S. (2012). Quiet: The power of introverts in a world that can't stop talking. New York, NY: Random House, Inc.

Cutrone, P. (2009). Overcoming Japanese EFL learners' fear of speaking. Language Studies Working Papers, 1, 55-63. Retrieved from https://www.semanticscholar.org/paper/OvercomingJapanese-EFL-Learners-\%E2\%80\%99-Fear-of-SpeakingCutrone/802ec28e5b0ab4082b2f6f71138c5af698a1bfe2

Harmer, J. (2007). The practice of English language teaching $\left(4^{\text {th }}\right.$ ed.). Harlow, LDN: Pearson Longman.

Hattie, J., \& Yates, G. (2014). Visible learning and the science of how we learn. Oxon: Routledge.

Hergenhahn, B., R., \& Olson, M. H. (2008). Theories of learning $\left(7^{\text {th }}\right.$ ed.). London: Pearson Education Limited.

Indrianty, S. (2016). Students' anxiety in speaking English (a case study in one hotel and tourism college in Bandung). ELTIN Journal, 4(1), 28-39. Retrieved from http://ejournal.stkipsiliwangi.ac.id/index.php/eltin/article/view/337
McDonough, J., Shaw, C., \& Masuhara, H. (2013). Materials and methods in ELT: A teacher's guide ( $3^{\text {rd }}$ ed.). Hoboken, NJ: WileyBlackwell

Martin, G. L., \& Osborne, J. G. (1989). Psychology, adjustment, and everyday living. New Jersey: Prentice Hall.

Palmer, E. (2014). Teaching the core skills of listening and speaking. Alexandria, VA: ASCD.

Pollard, L. (2008). Lucy Pollard's guide to teaching English: A book to help you through your first two years in teaching. Retrieved from

http://libgen.io/book/index.php?md5=68CBF2DCB008A64D509 B6F109E16B70F

Pritchard, A. (2014). Ways of learning: Learning theories and learning styles in the classroom ( $3^{\text {rd }} \mathrm{ed}$.). Oxon, OX: Routledge.

Schwartz, L. S. (2015). Childhood experiences of introversion: an exploration of navigating social and academic spaces and ways of coping. Theses, Dissertations, and Projects. Retrieved from https://scholarworks.smith.edu/theses/919

Schunk, D. H. (2012). Learning theories: An educational perspective $\left(5^{\text {th }}\right.$ ed.). Boston, MA: Pearson Education, Inc.

Zhiping, D., \& Paramasivan, S. (2013). Anxiety of speaking English in class among international students in a Malaysian University. International Journal of Education and Research, 1(11), 1-16. Retrieved from www.ijern.com

Zimmerman, B. J. (1998). Developing self-fulfilling cycles of academic regulation: An analysis of exemplary instructional models. In Schunk, D. H. \& Zimmerman, B. J (Eds.). Selfregulated learning: From teaching to self-reflective practice (pp. 1-19). New York, NY: The Guilford Press. 